\title{
Allocyclic and thermochronological constraints on the evolution of the Maritimes Basin of eastern Canada
}

\author{
R.J. Ryan ${ }^{1}$ and M. Zentilli 2

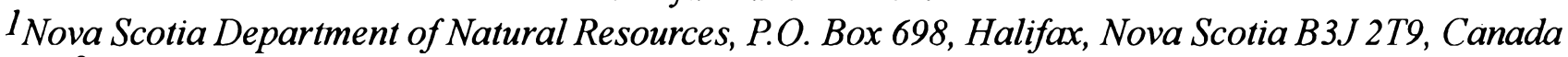 \\ 2 Department of Earth Science, Dalhousie University, Halifax, Nova Scotia B3H 3J5, Canada
}

Date Received July 7, 1993

Date Accepted December 3, 1993

\begin{abstract}
The tectonic and metallogenetic evolution of the Maritimes Basin is constrained by its thermochronology, structure, and stratigraphy. Allocyclic sedimentary deposition occurred within the basin and reflects the shifts in tectonic subsidence from local rapid events to regional slower events. Apatite thermochronology combined with vitrinite reflectance data suggest that an additional 1.5 to $4 \mathrm{~km}$ of strata were deposited prior to $280 \mathrm{Ma}$ and subsequently eroded. The organic maturation and the apatite fission track modelling indicate that the exhumation took place from 280 to $200 \mathrm{Ma}$. The thermochronology data are consistent with a paleogeothermal gradient of approximately $25^{\circ} \mathrm{C} / \mathrm{km}$. The structure of the Maritimes Basin and the paleogeographic reconstructions based on paleomagnetics and sediment dispersal studies suggest that the basin developed as a continental wrench-fault basin. The exhumation of the basin may be the result of pre-rift bulging or due to the erosion of strata deposited above sea level following a waning in the sediment supply into the basin. The timing of basin-brine expulsion events which have been hypothesized to explain $\mathrm{Pb}-\mathrm{Zn}-\mathrm{Ba}$ deposits in the basin are constrained to pre $280 \mathrm{Ma}$, prior to the onset of exhumation. Redbed $\mathrm{Cu}$ mineralization can be explained as being related to a period of reddening of the sandstones of the basin during the exhumation of the strata.
\end{abstract}

L'évolution tectonique et métallogénique du bassin des Maritimes est circonscrite par sa thermochronologie, sa structure et sa stratigraphie. La déposition sédimentaire allocyclique dans le bassin reflète les changements de subsidence tectonique, passant d'événements locaux rapides à des événements régionaux plus lents. La thermochronologie de l'apatite combinée aux données du pouvoir réflecteur de la vitrinite suggère que de 1,5 à $4 \mathrm{~km}$ additionnels de couches ont été déposés avant 280 Ma pour être ensuite érodés. La maturation organique et la modélisation des traces de fission dans l'apatite indiquent que la dénudation a eu lieu de 280 à $200 \mathrm{Ma}$. Les données thermochronologiques sont en accord avec un gradient paléogéothermique d'environ $25^{\circ} \mathrm{C} / \mathrm{km}$. La structure du bassin des. Maritimes et les reconstructions paléogéographiques basées sur des études paléomagnétiques et de dispersion des sédiments suggèrent que le bassin s'est développé comme un bassin continental lié à une faille de décrochement. La dénudation du bassin pourrait être liée à un bombement pré-rift ou à l'érosion des couches déposées au-dessus du niveau de la mer après le déclin d'apports sédimentaires dans le bassin. L'expulsion des saumures du bassin qui pourrait être à l'origine des minéralisations en $\mathrm{Pb}-\mathrm{Zn}-\mathrm{Ba}$ dans le bassin a eu lieu il y a du moins $280 \mathrm{Ma}$, avant le début de la dénudation. L'explication des minéralisations cuprifères dans les couches rouges peut-être liée à une période de rubéfaction des grès du bassin lors de l'érosion des couches.

[Traduit par la rédaction]

\section{INTRODUCTION}

The Maritimes Basin is primarily made up of continental clastic strata that presently cover a large area of onshore and offshore Atlantic Canada (Fig. 1). This study integrates three separate but interdependent components: (1) stratigraphy and tectonically induced sedimentary allocycles, (2) a detailed thermochronological study including apatite fission track analysis, and (3) a study of the structure of the basin centred on the Cumberland Basin. This paper demonstrates how these investigations constrain probable models for the tectonic and metallogenetic evolution of the Maritimes Basin.

\section{Allocycles}

Allocycles are cycles of sedimentation caused by forces external to the sedimentary processes taking place within the basin, for example, tectonism or climate change. The late Paleozoic to Mesozoic rocks in Atlantic Canada record a complex history of sedimentation, tectonics, and volcanism in the north- eastern Appalachians. Strata contained within successor basins reach a maximum thickness of $12 \mathrm{~km}$ (Howie, 1988) in the central Gulf of St. Lawrence (Magdalen Basin). These are represented by a complex molassic succession dominated by continental deposition. Sediments were derived both locally (especially in the Late Devonian and Early Carboniferous) and regionally (Late Carboniferous) from the Appalachian Orogen. Ryan et al. (1987) suggested that the stratigraphy of the DevonoCarboniferous basin-fill units in the southern Maritimes Basin can be divided into megasequences or allocycles. Based on this earlier work the basin-fill units of the southern Maritimes Basin can be divided into three allocycles: (1) the Fountain Lake Group to the Mabou Group of Upper Devonian to Namurian age (365-325 Ma), (2) the lower part of the Cumberland Group of Upper Namurian to mid-Westphalian A age (325-310 Ma), and (3) the upper part of the Cumberland Group and the Pictou Group of Late Westphalian A to Lower Permian age (310-280 Ma) (Fig. 2). Each megasequence (allocycle) records a deceleration of the subsidence rate. Initial rapid subsidence (and/or uplift) resulted in local deposition of fanglomerates at the basin 


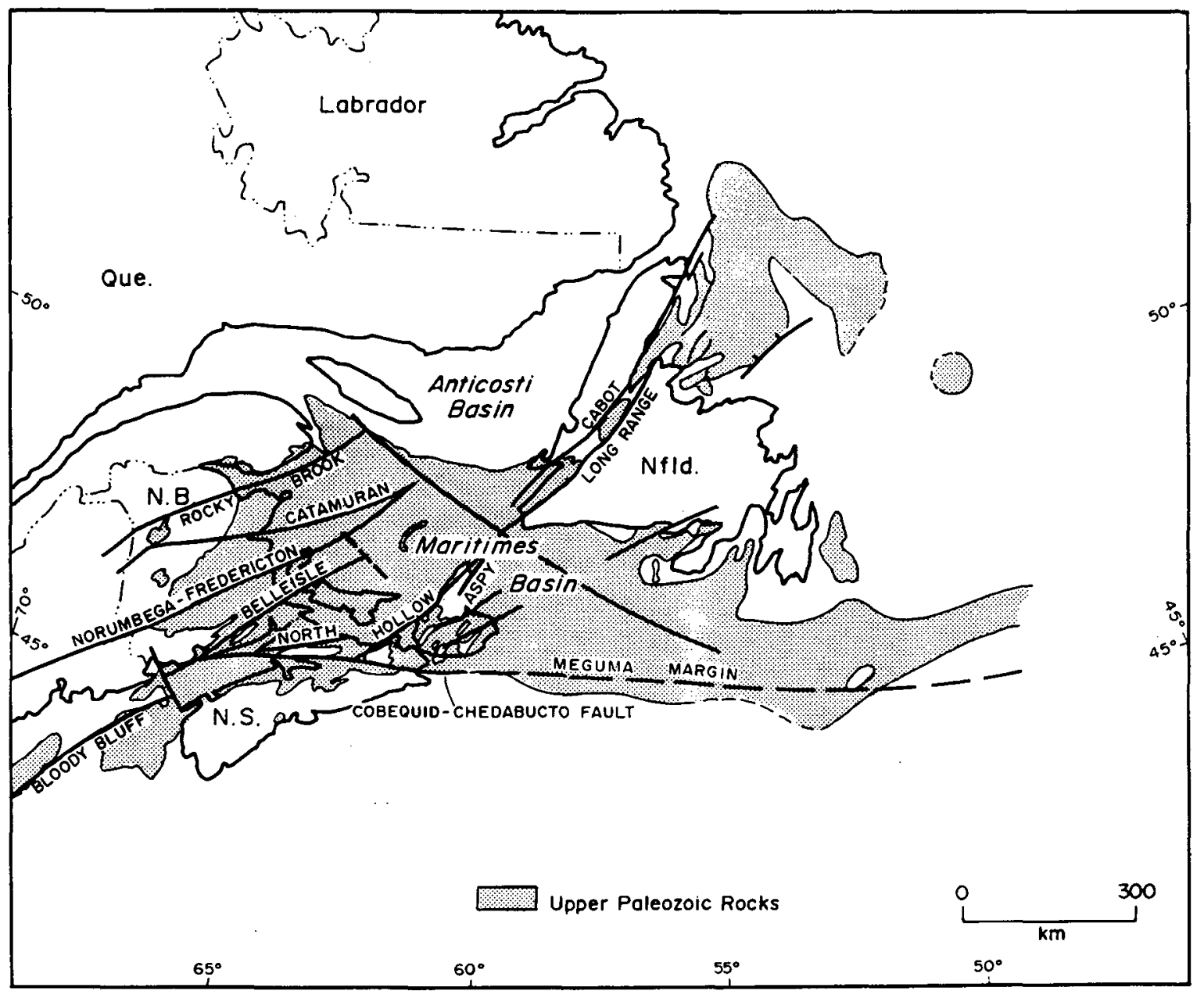

Fig. 1. Location map and simplified structural feature map of the Maritimes Basin in Atlantic Canada. The main structural components are the strike-slip and the thrust faults.

margins, which interfingered basinward into lacustrine sequences. These marginal coarse deposits were succeeded by a transition to fluvial, lacustrine, and in one case, marine basinfill. The later episodes of basin infilling were regionally extensive and overlapped older basin strata in some areas, reflecting a slower subsidence rate of more regional extent. These allocyclic packages are useful simplifications of the large-scale depositional trends and aid in understanding the relationships of local and regional tectonic activity. Each of the allocycles represents a shift from local rapid subsidence associated with net dip-slip movement along strike-slip faults, which results in fanglomerate and basinward lacustrine deposition, to regional subsidence associated with regional flexure due to terrane convergence, which resulted in the fluvial and/or marine deposition onlapping the basement blocks. These cycles which have been recognized in the Cumberland Basin (southern part of the Maritimes Basin) also occur on the larger basin-wide scale and aid in correlation of the basin-fill strata throughout the Maritimes Basin.

\section{ThermochronologY}

This paper contains a brief summary of the apatite fission track component of the detailed study carried out by Ryan (1993) which included: (1) vitrinite reflectance, (2) TAI (spore colour maturation method), (3) clay mineralogy, (4) fluid inclusions, (5) Rock-Eval pyrolysis, and (6) apatite fission track analysis. Due to space limitations only the fission track analysis is discussed and details of the other paleothermal indicators are not presented. It must be kept in mind that the thermochronological studies carried out by Ryan (1993) were designed to ascertain the time-temperature history trends in the Maritimes Basin as a whole. Ryan (1993) characterized the broad regional burial history trends so that they could be used as a basis for comparison for future studies. These regional trends thus serve as a baseline to assess the time-temperature histories within the domains of diapirs, faults, Carboniferous igneous activity, and/or in the areas where thick sequences of Triassic-Jurassic clastics and volcanics were deposited. Numerous areas within the Maritimes Basin have organic maturation values which indicate time-temperature histories which vary considerably from the overall trends presented here. These anomalous areas are the focus of ongoing research into the thermal and metallogenetic evolution of the Maritimes Basin.

\section{Apatite fission track results}

Fission tracks (FT) are damage zones created within solids when fission fragments travel through them. Following a fission event, two positively charged fission fragments are mutu- 


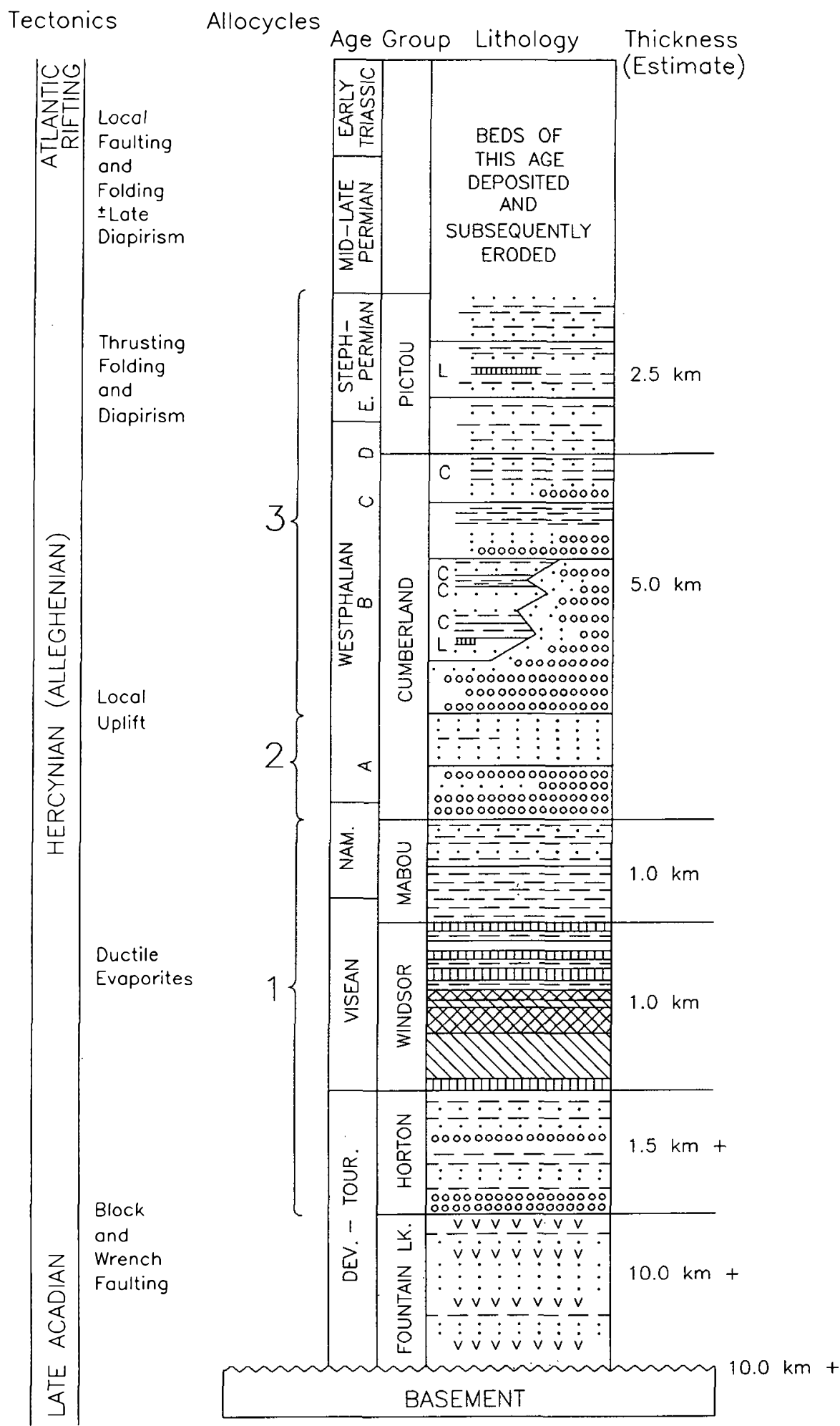

Fig. 2. Generalized stratigraphy. with corresponding allocycles and tectonics of the Maritimes Basin (modified after Ryan et al., 1991). Dots = sandstones; dashes = mudrocks; circles = conglomerates; v's = volcanics; $\mathrm{C}=$ coal; $\mathrm{L}$ or vertical lines $=$ limestone; cross hatch = salt; diagonal lines $=$ gypsum/anhydrite. Note that each allocycle has a conglomerate unit at the base and fines upward.

ally repelled, stripping electrons from the surrounding lattice. Repulsion from the trail of secondary positively charged ions embeds these particles into the surrounding lattice, forming a damage zone or fission track. Over the period of geologic interest only ${ }^{238} \mathrm{U}$ has a sufficiently short fission half life to create significant numbers of spontaneous tracks. Trace amounts of uranium occur within several common minerals, and because ${ }^{238} \mathrm{U}$ undergoes spontaneous fission at a known rate, fission tracks can be used to date the sample (Naeser et al., 1990). An age can be calculated by comparing the ratio of spontaneous fission tracks intersecting a polished mineral surface to the number of induced tracks observed on a mica detector (a measure of 
the total $U$ content). Apatite fission track dating depends on the amount of ${ }^{238} \mathrm{U}$ isotope present and how much has been converted to a daughter product, thus creating a fission track. Measurement of ${ }^{238} \mathrm{U}$ (parent) and the number of spontaneous fission tracks (daughter) is similar to other radiometric dating techniques which measure radiogenic and stable isotopes (i.e., U/ $\mathrm{Pb}, \mathrm{Rb} / \mathrm{Sr}$, and ${ }^{40} \mathrm{Ar} /{ }^{39} \mathrm{Ar}$ methods). The ${ }^{238} \mathrm{U}$ present is determined by irradiating a sample with a thermal-neutron flux which induces fissioning of ${ }^{235} \mathrm{U}$ in the sample. The ratio ${ }^{238} \mathrm{U} /$ ${ }^{235} \mathrm{U}$ is constant in nature, and a count of the induced ${ }^{235} \mathrm{U}$ fission tracks is used to indirectly measure the amount of ${ }^{238} \mathrm{U}$ present in a sample. The tracks themselves are not visible by normal transmitted light microscope methods unless these zones of weakness are chemically etched. If a mineral containing fission tracks is heated to high enough temperatures to displace ions along the damage zones, the ions will diffuse back into their normal position and the track will shorten and eventually disappear (anneal). The most commonly used minerals are apatite, which anneals between 85 and $120^{\circ} \mathrm{C}$ (ca. $100^{\circ}$ ), and zircon which anneals between 160 and $250^{\circ} \mathrm{C}$. The fission track studies carried out in the Maritimes Basin were on the apatites from the basin-fill units and the adjacent basement rocks.

The surface or near-surface results obtained for the strata in the Maritimes Basin have fission track ages which are younger than the depositional age of the rocks and therefore are interpreted as having been reset (Fig. 3). This means that all of the rocks have been subjected to temperatures $>100^{\circ} \mathrm{C} \pm$ as this is the temperature at which apatite fission tracks are reset (annealed). The apatite fission track ages therefore record the time at which the rocks were last exposed to temperatures of approximately $100^{\circ} \mathrm{C}\left(100^{\circ} \mathrm{C}\right.$ is used as it is the median of the annealing range of apatite). This paper uses data from several apatite fission track studies of the Maritimes Basin including: Ryan, 1993; Ryan et al., 1992; Hendriks et al., 1992; Hendriks, 1991; Ravenhurst et al., 1990; and Arne et al., 1990. For the sake of regional comparison, all the measured ages (Fig. 4) were arbitrarily corrected to a mean track length of 15.2 microns (length as measured by the author for the Fish Canyon Standard, similar lengths were measured by other workers in the lab for the same standard). This procedure is controversial and

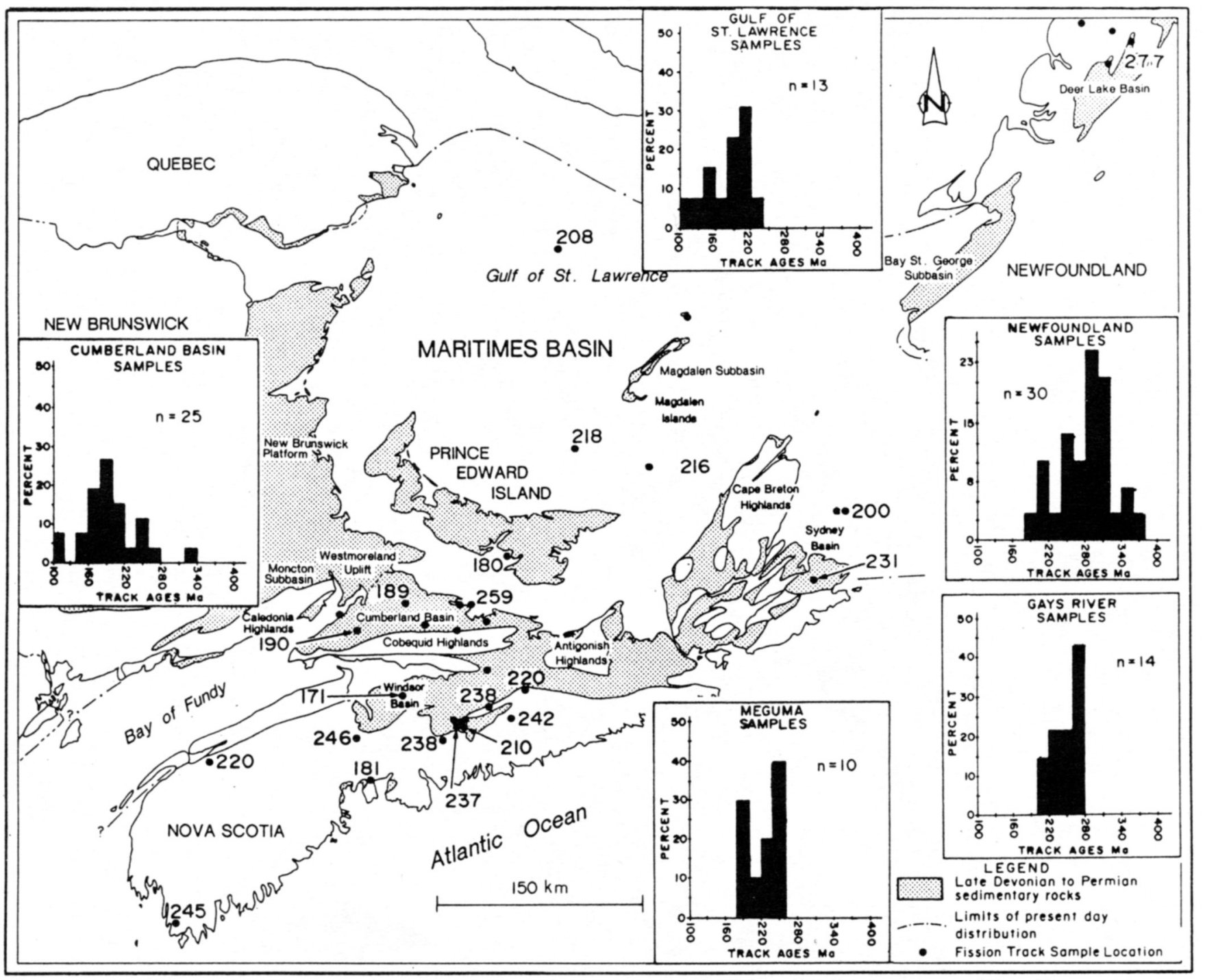

Fig. 3. Results of the apatite fission track studies in the Maritimes Basin. The results are given as ages corrected to an assumed initial track length of 15.2 microns. Numbers beside the sample points are individual ages for the near surface samples. The histograms represent summaries of results for the various areas within the basin and adjacent basement rocks. 


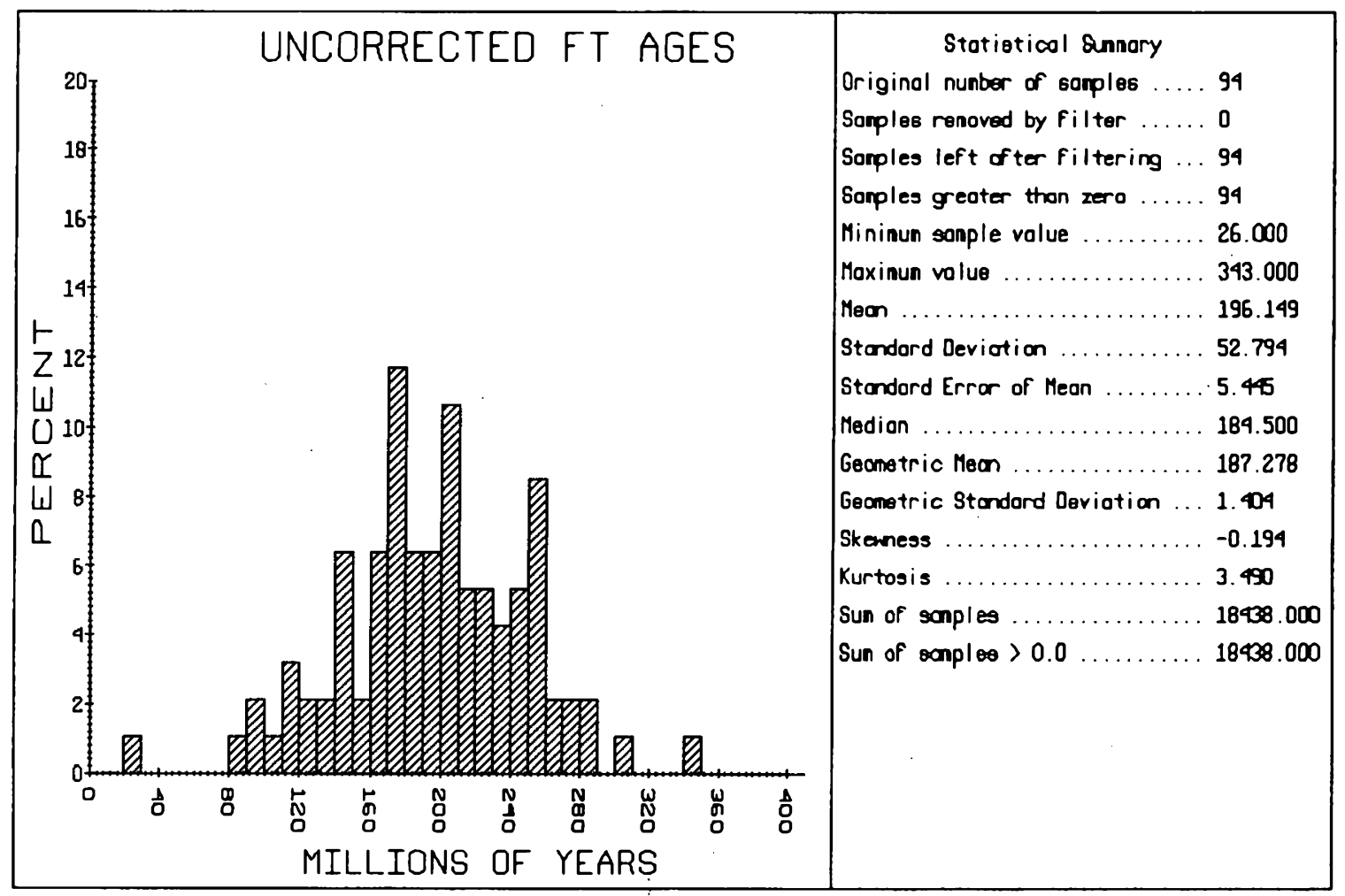

Fig. 4. Histogram of the uncorrected apatite fission track ages for the Maritimes Basin study, mean is $196 \pm 53$ Ma. The spread in the measured ages reflects the degree of shortening of the tracks with depth. There is a strong inverse relationship between the depth of the sample and the measured uncorrected apatite fission track age (for tables of the data see Ryan, 1993).

corrections of FT data should be introduced only with the utmost caution (e.g., Wagner, 1979; Gleadow et al., 1986; Green, 1988). Willett (1992) suggested that the $1: 1$ ratio of reduction of fission track length to reduction of fission track age is approximately correct for lengths greater than $65 \%$ of the original length given that the samples exhibit a unimodal symmetrical distribution of the track lengths. Ryan (1993) found that almost all of the samples from the Maritimes Basin have simple unimodal, symmetrical track length distributions suggesting that correction of fission track ages based on track length reduction was appropriate for the Maritimes Basin samples. Blind samples from the various Maritimes Basin FT studies were reanalyzed and the results were consistent with those of other workers, therefore, such a correction for age was possible. The only samples which cannot be reanalyzed were those of Arne et al. (1990) and therefore these data must be compared with caution. The apatite FT procedures for most of the Maritimes Basin data (exception are those of Arne et al., 1990) followed the methods described by Grist and Ravenhurst (1992).

Samples were taken from surface outcrop, shallow diamond drill holes, as well as from cuttings and cores in offshore petroleum exploration wells (Fig. 3). As far as possible, samples were selected at horizons for which organic maturation data were also available, to make comparison possible.

A total of 26 fission track ages were determined from 55 samples collected as part of the Cumberland Basin study (Ryan, 1993). The other samples did not contain sufficient numbers of etchable apatite grains to permit dating. The results of samples from Prince Edward Island, Scotch Village, and from the Sydney
Basin were carried out as part of the study and are included with the Cumberland Basin histogram (Fig. 3). This group of samples has a mean corrected age of $198 \pm 47 \mathrm{Ma}$.

In conjunction with the Cumberland Basin project, a parallel study of a series of offshore drill holes and wells in the Gulf of St. Lawrence was undertaken by the Dalhousie Fission Track Research Lab. Ryan et al. (1992) have summarized the results. The mean corrected age of the samples from surface to a depth of $2 \mathrm{~km}$ is $184 \pm 35 \mathrm{Ma}$ (Fig. 3).

Ravenhurst et al. (1990) and Arne et al. (1990) have done apatite fission track analysis on the Meguma Terrane south of the Cobequid-Chedabucto Fault zone. The samples were from both the Carboniferous strata and from the underlying Meguma Group and the South Mountain Batholith. For the purpose of this study these samples have been divided into those adjacent to the Gays River Deposit and those from other parts of southern Nova Scotia referred to as Meguma samples (Fig. 3). The Gays River samples have a mean corrected age of $249 \pm 22 \mathrm{Ma}$. The Meguma samples have a mean corrected age of $221 \pm 26$ Ma.

Hendriks (1991) carried out an apatite fission track study investigating the exhumation history of the Long Range Mountains in Newfoundland. His results have a direct bearing on the adjacent Deer Lake Basin which constitutes part of the larger Maritimes Basin. Samples from the Deer Lake Basin and the Long Range Mountains of Newfoundland give corrected ages of approximately $281 \pm 44 \mathrm{Ma}$ (Fig. 3).

The overall mean for the apatite fission track corrected ages from the Maritimes Basin is $232 \pm 55 \mathrm{Ma}$ (Fig. 5). Given the 


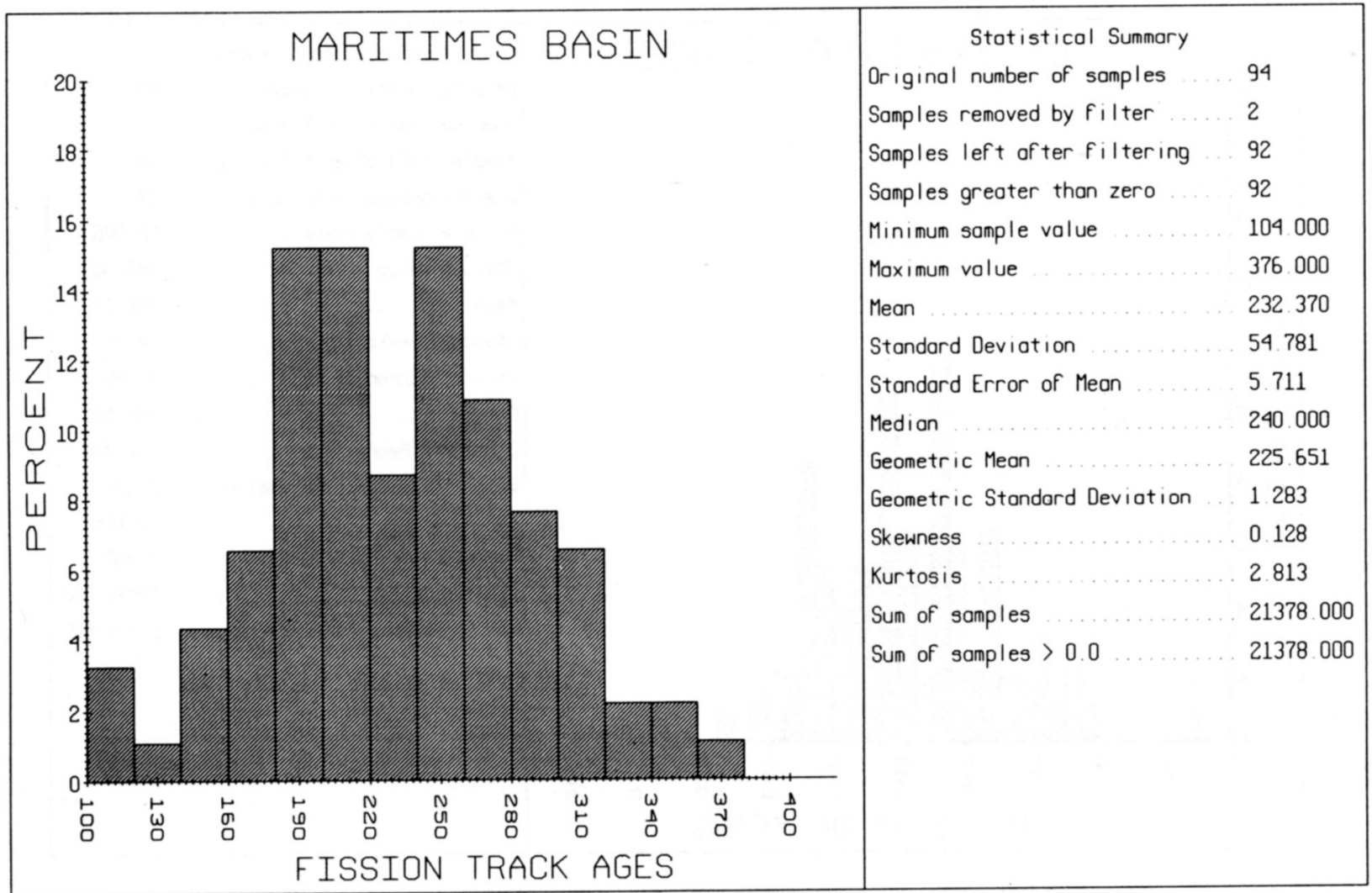

Fig. 5. Histogram of the corrected apatite fission track ages for the Maritimes Basin. Two samples have been filtered out of the data, one is a high elevation sample from the Long Range of Newfoundland and the other a deep sample from the Gulf of St. Lawrence drilling. The range in the ages reflects variations in the elevation and the depth of sampling from the well cuttings or cores.

organic maturation profiles for the basin, Ryan (1993) concluded that the temperatures necessary to reset the apatites were due to additional sedimentary cover. The overall Maritimes Basin fission track histogram indicates that there was a basin-wide exhumation of these additional strata ca. 280 to $200 \mathrm{Ma}$. The spread in the mean fission track ages can be explained by: (1) proximity to onlapped basin margins, (2) stratigraphic position of the sampled horizon, (3) duration of the exhumation event, (4) hot basin fluid expulsion events related to mineralization and faulting, and (5) analytical error.

\section{Interpretation of data}

Ryan (1993) modelled the stratigraphic and thermal data from the Maritimes Basin taking into account all of the thermal indicators. Burial history plots were constructed for the various parts of the Maritimes Basin based on stratigraphic, structural and thermal constraints, and time-temperature paths were determined. The time-temperature paths extrapolated from the burial history plots were then used in forward modelling of the fission track data as a means of further evaluating the validity of the paths. This modelling was accomplished by using the Trac3 forward model developed at Dalhousie University. Willett (1992) described in detail a forward model (Trac8) which is the updated version of the model used in this study; the model varies from Trac 3 in that it provides a statistical measurement in the degree of correlation between measured and modelled track length distributions. This feature is useful but not essential for the modelling data from the Maritimes Basin. In this study there was a good correlation of the measured versus the modelled fission track length distributions and ages when the time-temperature paths derived from the burial history plots were used and therefore the paths were assumed to be approximately correct. Figure 6 is a representative example of the modelling. Although other authors (e.g., Hacquebard, 1986) had already suggested the previous existence of additional cover, this study, through the use of apatite fission track analysis, is the first one to accurately constrain the timing of this additional cover throughout the whole basin. The fission track study also permitted a better interpretation of the other thermal indicators and provided the thread that tied all of the thermal data together.

The modelling of the quantitative thermochronological evidence from this study suggests that an additional thickness of 1.5 to $4 \mathrm{~km}$ of strata were deposited throughout the Maritimes Basin during the period up to $280 \mathrm{Ma}$. These sediments accumulated to a maximum thickness in the Permian and were eroded during an exhumation that preceded the Triassic/Jurassic rifting of the Atlantic margin (ca. $200 \mathrm{Ma}$ ). The Maritimes Basin therefore represents only an erosional remnant of a much larger basin of deposition. The additional sedimentary cover and its subsequent erosion or exhumation explains why the structure and diagenetic state of the strata at the present day surface are difficult to interpret. The suggestion that the Maritimes Basin is an erosional remnant of a formerly much larger basin (Fig. 7) has direct bearing on the organic maturation, the basin form- 

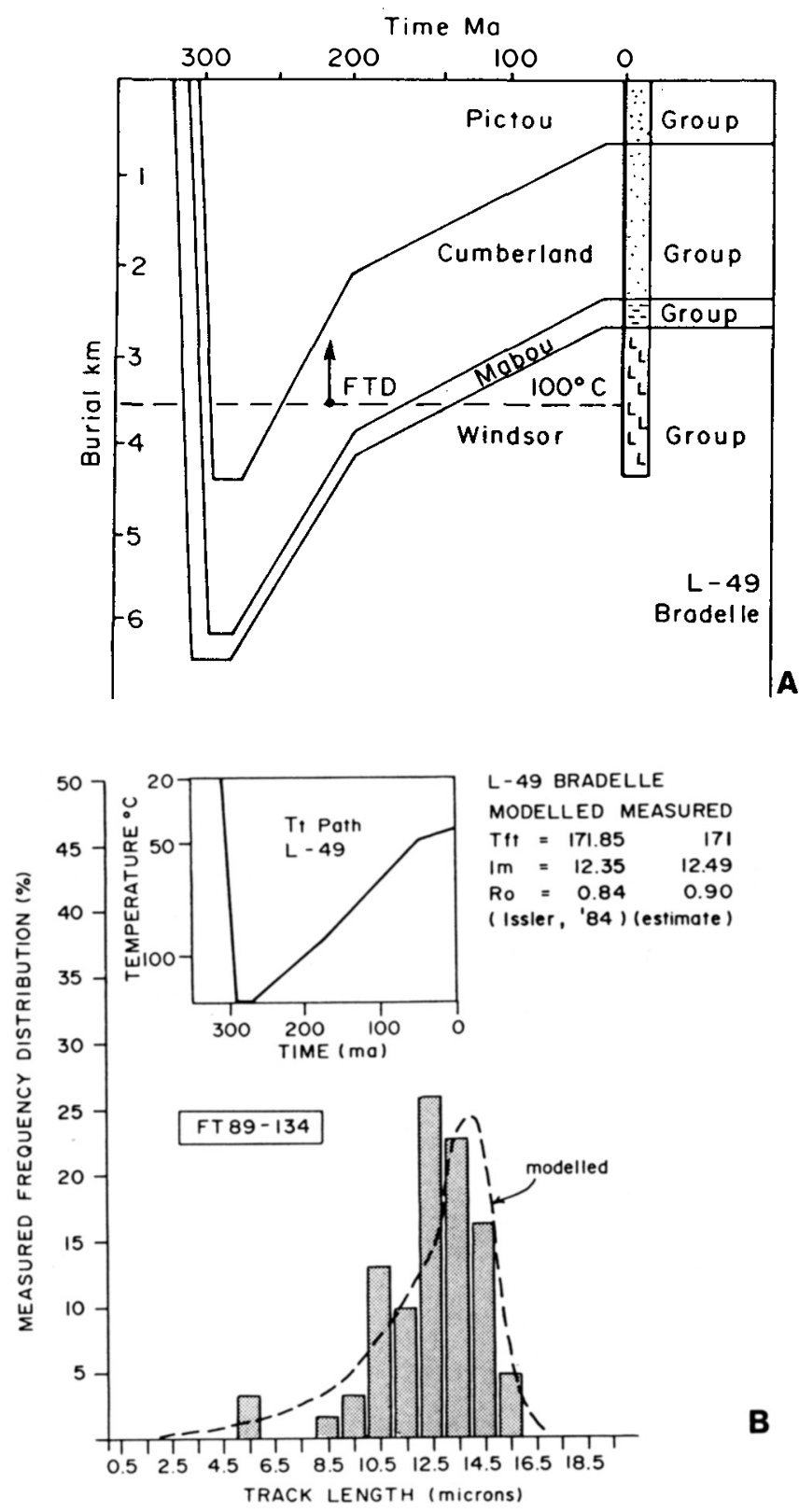

Fig. 6. (A) An example of a burial history plot and time-temperature path constructed using organic maturation profiles, stratigraphy and other thermal indicators. FTD is the apatite fission track age at the sampled stratigraphic position. (B) This is a model of the apatite fission track age and track length distribution using the time-temperature path derived from the burial history plot. The dashed line is the modelled distribution and the histogram represents the measured values. $\mathrm{Tft}=$ Fission track age; $1 \mathrm{~m}=$ mean track length; Ro $=$ vitrinite reflectance value.

ing mechanisms, and the metallogenesis in the Maritimes Basin. Interpretation of the geological record, both within and adjacent to the basin, must take the additional sedimentary cover into account. Most organic maturation models do not easily lend themselves to the modelling of a basin that is an erosional remnant and therefore the interpretation of (post-maximum burial) exhumation of a basin is an important factor to consider before embarking on modelling in any basin. Paleogeothermal gradients estimated from the thermochronological modelling were consistent with a continental origin for the basin.

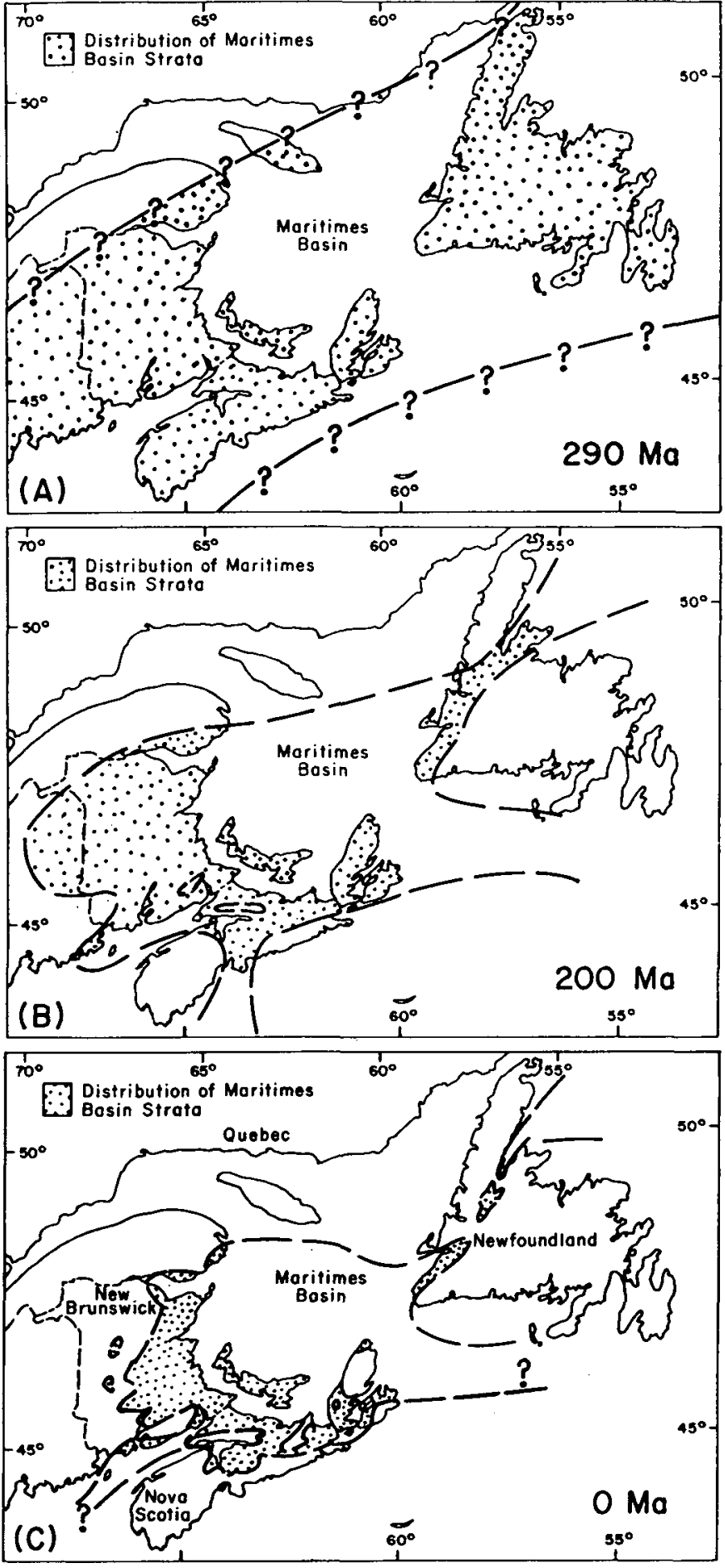

Fig. 7. Diagrammatic representation of the possible extent of PermoCarboniferous sedimentary cover through time (after Ryan et al., 1991). Whereas all of the rocks in the basin and the adjacent basement blocks have reset apatite fission track ages it is assumed that the basin must have covered most of the region 280 million years ago and have been subsequently eroded prior to 200 million years ago.

\section{STRUCTURE}

Essentially two tectonic models for the development of the Maritimes Basin have emerged from a multitude of hypotheses: (1) a rift model on a wrench system proposed by Belt (1968) and (2) a dextral strike-slip pull-apart model proposed by Brad- 
ley (1982). The most significant structural components of the Maritimes Basin are the east-west strike-slip faults and the associated westerly directed thrusts. McCutcheon and Robinson (1987) suggested that the key to understanding the tectonics lies in a better understanding of the kinetics of the CobequidChedabucto and the Belleisle faults. These faults, together with the Long Range, Taylors Brook, Green Bay, Hollow, Aspy, Norumbega, and Fredericton faults, hold the key to understanding the tectonic framework. A detailed investigation of all of these structural features is beyond the scope of this paper, however, valuable information about movement along the CobequidChedabucto Fault and its subsidiaries were derived from the Cumberland Basin area (Ryan, 1993).

Ryan (1993) concluded that a minimum of $20 \mathrm{~km}$ of strikeslip offset occurred along the Cobequid-Chedabucto Fault and its subsidiaries and that displacement may have perhaps been as much as $200 \mathrm{~km}$. In addition to the strike-slip movement there has been episodic dip-slip movement as evidenced by the fanglomerates adjacent to highland areas near these fault zones. These fanglomerates mark the base of the sedimentary allocycles discussed earlier in this paper.

\section{IMPLICATIONS}

The Maritimes Basin lies at the northern edge of the Appalachian Orogen and the basin-fill is derived from the
Mauritanides of West Africa and the Appalachians Mountains in the south (Gibling et al., 1991). Detritus eroded from these mountains was transported longitudinally between the mountain ranges to the Maritimes Basin which acted as a receiving basin. The basin may have developed because of the gradient break created by the numerous strike-slip faults in the area (Fig. 8). Our thermochronological studies indicate that the paleogeothermal gradients were relatively low (ca. $25^{\circ} \mathrm{C} / \mathrm{km}$ ) placing constraints on the tectonic setting of the basin and suggesting a continental origin for the basin. These low geothermal gradients cast doubt on the role of crustal thermal anomalies in the formation of the basin during the Carboniferous. The thermochronology also indicates that the present distribution of basin strata is far less extensive than the original basin of deposition. The basin can be classified as a continental wrench basin on the basis of the structural geology, tectonic setting and the allocyclic basin-fill stratigraphy. Analogous basins are the more recent Malay Basin and related basins developed near the South China Sea (Kingston et al., 1983).

Perhaps the most important inference that can be made from the thermal study of the Maritimes Basin is that there was removal of 1.5 to $4.0 \mathrm{~km}$ of strata from the Maritimes Basin, starting in the Late Permian. The problem arises in the interpretation of such a process. What was the driving mechanism for such a uniform exhumation throughout an entire basin? In examining burial history plots and the time-temperature plots,

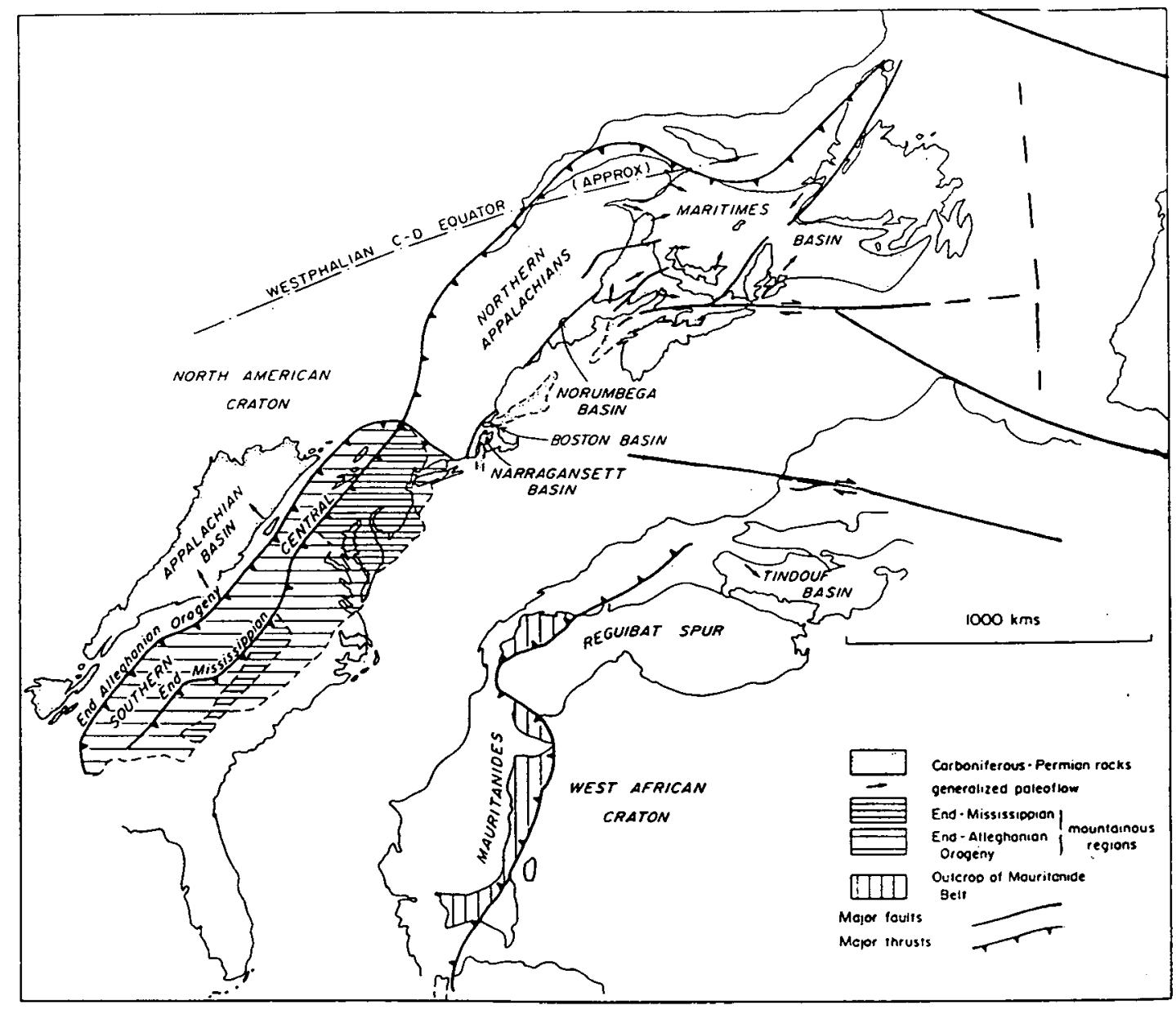

Fig. 8. Paleogeographic reconstruction of the late Pennsylvanian along the Appalachian Orogen (after Gibling et al., 1991). 
it is clear that this mechanism caused a remarkably consistent exhumation throughout the basin. In the early stages of this study, it was postulated that the erosion (exhumation) may have been related to a pre-rift bulge stage related to the opening of the Atlantic. However, as evidenced by the apatite fission ages, exhumation continued to occur after this rifting was initiated.

Rapid sedimentation rates for the basin-fill units in the Maritimes Basin (Ryan, 1993) indicate that the basin was receiving an enormous volume of material throughout the PermoCarboniferous. If the Maritimes Basin represents the first break in the steep gradient between two mountain ranges, the result could be an overfilled basin, thus raising the baselevel above sea level. This overfilling of the basin would continue at a steady state as long as there was a constant contribution of detrital material entering the basin. As the transport of the material waned, the basin surface must have been peneplained during isostatic rebound to a level of approximately sea level. If 1 to 4 $\mathrm{km}$ of basin-fill has been removed, it would require sedimentation to have occurred at elevations up to $1 \mathrm{~km}$ above sea level, based on isostatic rebound calculations and assuming that erosion to sea level is the driving mechanism causing the exhumation.
There are several fission track studies in the North Atlantic region which also record a period of exhumation at approximately the same time as the exhumation of the Maritimes Ba$\sin$ (Fig. 9). The crystalline basement of southeastern Norway yields uncorrected apatite fission track ages of 160 to $260 \mathrm{Ma}$ (Andriessen, 1990). Similar data has been obtained in the Brabant Massif, Belgium (Van den Haute and Vercoutere, 1989) and in the southern Fennoscandian Shield (Zeck et al., 1988). All of these areas studied suggest Late Paleozoic burial and Pre-Jurassic exhumation. The significance of these coincident exhumations is not clear at this time but certainly worthy of further investigation.

The additional cover suggested by this study and subsequent exhumation place time constraints on the basin-brine expulsion mineralizing models proposed for the basin. This study neither confirms nor denies the validity of the basin-brine expulsion model as proposed by Ravenhurst and Zentilli (1987), however, if such an event took place it must have occurred prior to the onset of the exhumation event, that is before $280 \mathrm{Ma}$. The diagenetic process of reddening that affected the Upper Paleozoic sandstone hosts to the $\mathrm{Cu}-\mathrm{Ag}$ deposits in the Cumberland Basin must have been active during the time of

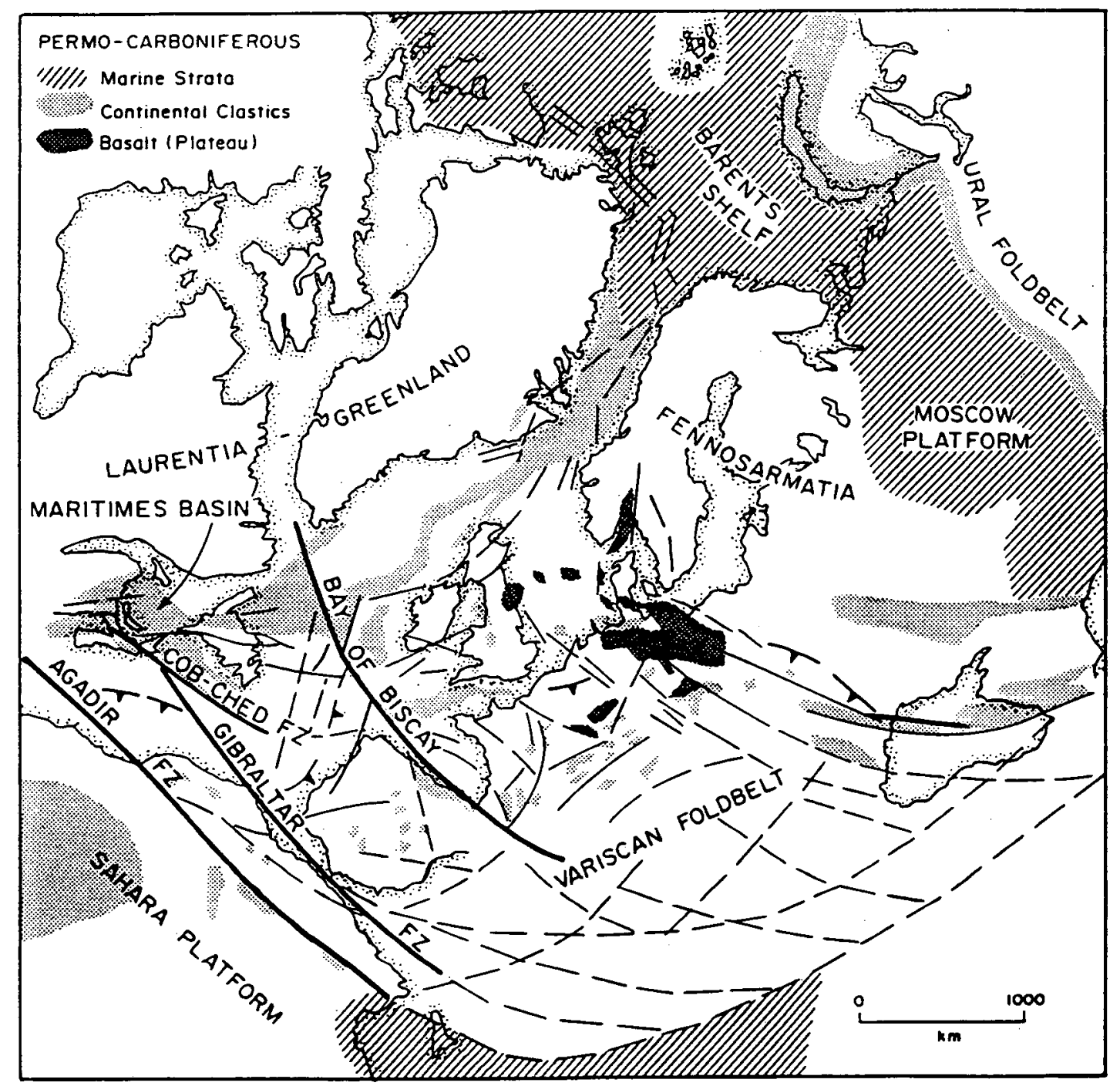

Fig. 9. Reconstruction of the northern hemisphere for the Stephanian (after Ziegler, 1989). Note the relationship of the Maritimes Basin to Belgium and Norway which underwent exhumation at the same time. 
exhumation of these strata. The reddening has been dated by paleomagnetic studies as Late Permian. The reddening of the sandstones has been linked to the mineralization by Ryan $e t$ al. (1989), and the timing of the reddening corresponds well with the exhumation of the basin. This exhumation provided the opportunity for the permeable sandstones of the basin to be infiltrated by oxygenated groundwaters that leached $\mathrm{Cu}-\mathrm{Ag}$ and associated elements from the sandstones and concentrated these elements in areas where reductants were encountered. The metallogenetic implications of the thermochronology and tectonic setting of the basin are the subject of ongoing research (see Ryan and Zentilli, in preparation; Ryan, 1993; Ryan et al., 1992).

\section{ACKNOWLedGements}

The authors would like to acknowledge the support of the Nova Scotia Department of Natural Resources for supporting R.J. Ryan during his Ph.D. studies at Dalhousie University. Marcos Zentilli would like to acknowledge the support grants by Esso Canada Limited and the support of the Department of Energy, Mines and Resources Canada. The authors benefitted by discussions with R. Boehner, P. Reynolds, A. Grist, and M. Gibling. The authors would also like to thank Peter Hacquebard and Dale Issler for reviewing this paper.

ANDRIESSEN, P.D.M. 1990. Anomalous fission track apatite ages of the PreCambrian basement in the Hunnedalen regime, southeastern Norway. Nuclear Tracks and Radiation Measurement, 17, pp. 285 291

ARne, D.C., DudDY, I.R., and SANGster, D.F. 1990. Thermochronological constraints on the timing of ore formation at the Gays River Pb$\mathrm{Zn}$ deposit, Nova Scotia, Canada, from apatite fission track analysis. Canadian Journal of Earth Science, 27, pp. 1013-1022.

Belt, E.S. 1968. Post-Acadian rifts and related facies, eastern Canada. In Studies in Appalachian Geology. Edited by E-an Zen, W.S. White, J.B. Hadley and J.B. Thompson. New York, Interscience, pp. 95-116.

Bradley, D.C. 1982. Subsidence in Late Paleozoic Basins in Northern Appalachians. Tectonics, 1, pp. 107-123.

Gibling, M.R., Calder, J.H., Ryan, R.J., van de Poll, W., and Yeo, G. 1991. Pennsylvanian and Permian paleoflow in Atlantic Canada. Canadian Journal of Earth Science, 28, pp. 1157-1169.

Gleadow, A.J.W., Duddy, I.R., and Lovering, J.F. 1986. Fission Track Analysis: A New Tool for the Evaluation of Thermal Histories and Hydrocarbon Potential. Australian Petroleum Exploration Association, 23, pp. 93-102.

GreEN, P.F. 1988. The Relationship Between Track Shortening and Fission Track Age Reduction in Apatite: Combined Influences of Inherent Instability, Annealing Anisotropy, Length Bias and System Calibration. Earth and Planetary Science Letters, 89, pp. 335352.

Grist, A.M. and Ravenhurst, C.E. 1992. A step-by-step Laboratory guide to fission track thermochonology at Dalhousie University. In Short Course Handbook on Low Temperature Thermochronolgy. Edited by M. Zentilli and P.H. Reynolds. Mineralogical Association of Canada, 20, pp. 189-210.

Hacquebard, P.A. 1986. The Gulf of St. Lawrence Carboniferous Basin: the largest coalfield of eastern Canada. Canadian Institute of Mining and Metallurgy Bulletin, 79, pp. 67-78
HendRIKs, M. 1991. Apatite fission track analysis of the Great Northern Peninsula of Newfoundland: evidence of Late Paleozoic burial. Unpublished M.Sc. thesis, Dalhousie University, Halifax, Nova Scotia, $230 \mathrm{p}$.

Hendriks, M., Jamieson, R.A., Zentilli, M., and Reynolds, P.H. 1992. Exhumation of Crystalline Basement rocks: low-temperature thermochronology of the Long Rage Inlier. In Short Course Handbook on Low Temperature Thermochronology. Edited by M. Zentilli and P.H. Reynolds. Mineralogical Association of Canada, 20, pp. 119-137.

HowIE, R.D. 1988. Upper Paleozoic evaporites of Southeastern Canada. Geological Survey of Canada, Bulletin 380, $120 \mathrm{p}$.

IsSLER, D.R. 1984. Calculation of organic matter maturation for the offshore eastern Canada - implications for the general application of Lopatin's method. Canadian Journal of Earth Science, 21, pp. $477-488$.

Kingston, D.R., Dishroon, C.P., and Williams, P.A. 1983. Global basin classification system. American Association of Petroleum Geology Bulletin, 67, pp. 2175-2193.

McCuTCheon, S.R. and Robinson, P.T. 1987. Geological constraints on the genesis of the Maritimes Basin, Atlantic Canada. In Sedimentary Basins and Basin Forming Mechanisms. Edited by $\mathrm{C}$. Beaumont and A.J. Tankard. Canadian Society of Petroleum Geologists, Memoir 12, and Atlantic Geoscience Society, Special Publication 5, pp. 287-297.

Naeser, N.D., Naeser, C.W., and McCulloh, T.H. 1990. Thermal history of rocks in southern San Joaquin Valley, California, Evidence from apatite fission track analysis. American Association of Petroleum Geologists Bulletin, 74, pp. 13-29.

Ravenhurst, C.E. and Zentilli, M. 1987. A model for the evolution of hot $\left(>200^{\circ} \mathrm{C}\right)$ overpressured brines under an evaporite seal; the Fundy/Magdalen Carboniferous Basin of Atlantic Canada and its associated $\mathrm{Pb}-\mathrm{Zn}-\mathrm{Ba}$ deposits. Canadian Society of Petroleum Geologists, Memoir 12, pp. 335-349.

Ravenhurst, C., Zentilli, M., Reynolds, P., Donelick, R., and BeauMONT, C. 1990. A Fission track pilot study of the thermal effects of rifting on the onshore Nova Scotia Margin, Canada. Nuclear Tracks and Radiation Measurement, 17, pp. 373-378.

Ryan, R.J. 1993. Metallogenetic ànd thermal evolution of the Upper Paleozoic Maritimes Basin: Evidence from the Cumberland Basin of Nova Scotia. Unpublished Ph.D. thesis, Dalhousie University, $333 \mathrm{p}$

Ryan, R.J., CAlder, J.H., Donohoe, H.V. JR., and Naylor, R. 1987. Sedimentation and basin evolution adjacent to the Cobequid Highlands Massif, Eastern Canada. In Basins and basin forming mechanisms. Edited by C. Beaumont and A. Tankard. Canadian Society of Petroleum Geologists, Memoir 12, pp. 311-317.

Ryan, R.J., Boehner, R.C., Stea, R.R., and Rogers, P.J. 1989. Geology, geochemistry, and exploration applications for the PermoCarboniferous redbed copper deposits of the Cumberland Basin, Nova Scotia, Canada. In Sediment hosted stratiform copper deposits. Edited by R. Boyle, A. Brown, C. Jefferson, C. Jowett and R. Kirkham. Geological Association of Canada, Special Paper 36 , pp. 245-256

RyAN, R.J., GRIST, A., and Zentilli, M. 1991. The thermal evolution of the Maritimes Basin: Evidence from apatite fission track analysis. In Nova Scotia Department of Mines and Energy, Report of Activities. Edited by D. MacDonald. Nova Scotia Department of Mines and Energy, Report 91-1, pp. 27-32.

1992. The Paleozoic Maritimes Basin of Eastern Canada, Metallogenetic implications of a fission track study. In Short Course Handbook on Low Temperature Thermochronology. Edited by $\mathrm{M}$. Zentilli and P. Reynolds. Mineralogical Association of Canada, 20, pp. 141-156. 
Van den Haute, P. and Vercoutere, C. 1989. Apatite fission track evidence for Mesozoic uplift of the Brabant Massif: Preliminary Results. Annales de la Societe Geologique de Belgique, 64, pp. 1245-1276.

WAGNER, G.A. 1979. Correction and interpretation of fission track ages. In Lectures in Isotope Geology. Edited by Jager and Hunziker. pp. 170-177.

WiLLETT, S.D. 1992. Modelling thermal annealing of fission track in apatite. In Short Course Handbook on Low Temperature
Thermochronology. Edited by M. Zentilli and P.H. Reynolds. Mineralogical Association of Canada, 20, pp. 43-74.

Zeck, H.P., Andriessen, P.D.M., Hansen, K., Jensen, P.K., and Rasmussen, B.L. 1988. Paleozoic paleo-cover of the southern Fennoscandian Shield - fission track constraints. Tectonophysics, 149, pp. 61-66

ZIEGLER, P.A. 1989. Evolution of the Arctic-North Atlantic and the Western Tethys. American Association of Petroleum Geologists, Tulsa, Oklahoma, Memoir 43. 